\title{
PENGARUH PENDIDIKAN AGAMA ISLAM TERHADAP AKHLAK PESERTA DIDIK
}

\author{
Acep Ceptian Nurpajar \\ Institut Agama Islam Latifah Mubarokiyah Suryalaya Tasikmalaya \\ acepceptiannurpajar@gmail.com, Arifgustiana100@gmail.com
}

\begin{abstract}
Abstrack
This study aims to determine the effect of Islamic religious education on the morals of students at MTs Al-Mansyur Hujungtiwu, Panjalu District. This study uses a descriptive method with a quantitative approach. The study population was 142 respondents and a sample of 35 people. Based on the results of the research that: Islamic Religious Education at MTs Al-Mansyur Hujungtiwu District of Panjalu has been carried out well, it is proven that the score is 67.3 with good criteria. The morals of students at MTs Al-Mansyur Hujungtiwu, Panjalu District are generally good, as evidenced by a value of 60.87 with criteria including good. The influence of Islamic Religious Education on the morals of students at MTs AlMansyur Hujungtiwu, Panjalu District, is high as evidenced by a correlation value of 0.80 with a high classification. The contribution given by Islamic Religious Education was 64\%, and the rest was $36 \%$. There is a significant influence between Islamic Religious Education on the morals of students as evidenced by the $t$ value of $=7,659$. While t table $=1.687$.
\end{abstract}

Keywords: Islamic religious education, morals, students.

\begin{abstract}
Abstrak
Penelitian ini bertujuan untuk mengetahui Pengaruh pendidikan agama Islam terhadap akhlak peserta didik di MTs Al-Mansyur Hujungtiwu Kecamatan Panjalu. Penelitian ini menggunakan metode deskriptif dengan pendekatan kuantitatif. Populasi penelitian sebanyak 142 responden dan sampel sebanyak 35 orang. Berdasarkan hasil penelitian bahwa: Pendidikan Agama Islam di MTs Al-Mansyur Hujungtiwu Kecamatan Panjalu sudah dijalankan dengan baik dibuktikan perolehan nilai sebesar 67,3 dengan kriteria baik. Akhlak Peserta Didik di MTs Al-Mansyur Hujungtiwu Kecamatan Panjalu pada umumnya sudah baik dibuktikan dengan nilai sebesar 60,87 dengan kriteria termasuk baik. Pengaruh Pendidikan Agama Islam terhadap akhlak peserta didik di MTs Al-Mansyur Hujungtiwu Kecamatan Panjalu tergolng tinggi dibuktikan dengan nilai korelasi sebesar 0,80 dengan klasifikasi tinggi. Besar kontribusi yang diberikan Pendidikan Agama Islam sebesar 64\%, dan sisanya sebesar 36\%. Terdapat pengaruh yang signifikan antara Pendidikan Agama Islam terhadap Akhlak peserta didik dibuktikan dengan nilai t hitung sebesar $=7.659$. Sedangkan $\mathrm{t}$ tabel $=1,687$.
\end{abstract}

Kata kunci: Pendidikan Agama Islam, akhlak, Peserta Didik. 


\section{A. PENDAHULUAN}

Pendidikan adalah usaha sadar dan terencana untuk mewujudkan suasana belajar dan proses pembelajaran agar peserta didik secara aktif mengembangkan potensi dirinya untuk memiliki kekuatan spiritual keagamaan, pengendalian diri, kepribadian, kecerdasan, akhlak mulia, serta keterampilan yang diperlukan dirinya, masyarakat, bangsa dan negara (UU Sistem Pendidikan Nasional, 2003:3).

Pendidikan agama Islam merupakan bagian yang tak terpisahkan dari system pendidikan di Indonesia, sebagaimana yang tercantum dalam Undang-undang nomor 20 tahun 2003 tentang Sistem Pendidikan Nasional pasal 12 ayat 1 butir a "Setiap peserta didik pada setiap satuan pendidikan berhak mendapatkan pendidikan agama sesuai dengan agama yang dianutnya dan diajarkan oleh pendidik yang seagama".

Sasaran pendidikan agama tertuju pada pembentukan sikap akhlak atau mental anak didik dalam hubungan dengan Tuhan, masyarakat dan alam atau sesama makhluk. Anak adalah cerminan masa depan, pendidikan anak harus benar-benar diperhatikan agar bakat mereka tersalurkan dalam kegiatan yang positif, yaitu diantaranya dengan memasukkan anak ke dalam jenjang pendidikan yang formal ataupun yang non formal.

Penanaman nilai agama kepada mereka merupakan syarat mutlak untuk mencapai nilai keharmonisan dalam menjalani kehidupan dunia dan akhirat. Nilai-nilai tersebut dapat dijadikan pondasi agar mereka tidak keluar dari ajaran-ajaran agama.

Pada tingkatan Madrasah Tsanawiyah (MTs) pendidikan agama Islam diajarkan sejak kelas satu sampai kelas tiga. Pelajaran ini berisikan keimanan, akhlak, al-Qur'an Hadits, ibadah dan tarikh. Yang juga di dalamnya menyangkut teori hukum Islam yaitu tentang kewajiban manusia, khususnya kewajiban individual kepada Allah swt .

Pada prinsipnya pendidikan agama Islam membekali siswa agar memiliki pengetahuan lengkap tentang hukum Islam dan mampu mengaplikasikannya dalam bentuk ibadah kepada Allah. Dengan demikian siswa dapat melaksanakan ritual-ritual ibadah yang benar menurut ajaran Islam sesuai dengan ibadah yang dipraktekkan dan diajarkan Rasulullah SAW, sehingga terwujud suatu konsep akhlak baik yang bersumber dari pengimplementasian pendidikan agama Islam.

Akhlak pada dasarnya melekat dalam diri seseorang, bersatu dengan perilaku atau perbuatan. Jika perilaku yang melekat itu buruk, maka disebut akhlak yang buruk atau akhlak mazmumah. Sebaliknya, apabila perilaku tersebut baik disebut akhlak mahmudah. Akhlak tidak terlepas dari aqidah dan syariah. Oleh karena itu, akhlak merupakan pola tingkah laku yang mengakumulasikan aspek keyakinan dan ketaatan sehingga tergambarkan dalam perilaku yang baik.

Akhlak merupakan perilaku yang tampak ( terlihat ) dengan jelas, baik dalam kata-kata maupun perbuatan yang termotivasi oleh dorongan karena Allah. Namun demikian, banyak pula aspek yang berkaitan dengan sikap batin ataupun pikiran, seperti akhlak diniyah yang berkaitan dengan berbagai aspek, yaitu pola perilaku kepada Allah, sesama manusia, dan pola perilaku kepada alam.

Masalah akhlak menjadi barometer tinggi rendahnya derajat seseorang. Hal ini sesuai dengan sabda Rasulullah SAW: 


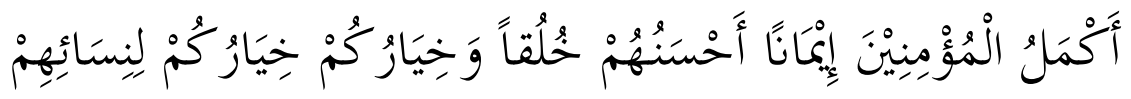

“Orang yang paling beriman adalah yang terbaik budi pekertinya, dan sebaikbaiknya kalian adalah yang berperilaku paling baik terhadap istri." (H. R. Tirmidzi).

Dari pemaparan hadist tersebut, dapat dipahami bahwa setiap orang dituntut harus dan berupaya memiliki memperbiki ahlaknya supaya lebih baik dan mampu diaplikasikan dalam kehidupannya.

Berkaitan dengan akhlak peserta didik di lingkungan Madrasah Tsanawiyah Al Manshur Kecamatan Panjalu, seharusnya mereka memiliki akhlak baik yang diperoleh melalui pembentukan akhlak melalui pendidikan agama islam yang mereka terima. Tetapi pada kenyataannya masih banyak peserta didik yang memiliki akhlak kurang baik, hal ini sesuai dengan fakta-fakta yang ada pada saat ini yaitu peserta didik terkadang sering berbohong, Padahal melalui pendidikan agama islam diarahkan untuk tidak melakukan hal tersebut. Sebagian peserta didik sering melalaikan ibadah, terkadang sebagian peserta didik sering melawan perintah dan nasihat orang yang lebih tua, peserta didik yang sering mengucapkan kata-kata kasar, dan yang tidak mencerminkan seorang peserta didik yang telah dibina dalam sistem pendidikan agama islam.

Fenomena tersebut mengindikasikan bahwa upaya pembinaan akhlak peserta didik yang diselnggarakan pihak pendidikan kurang terealisasi sesuai target, hal ini dikhawatirkan akan mendorong peserta didik memiliki akhlak yang buruk di dalam kesehariannya, baik itu di rumah, di sekolah, maupun di lingkungannya, dan berangsurangsur sampai peserta didik beranjak dewasa. Tentu hal itu akan merugikan dirinya sendiri, keluarga dan orang disekitarnya.

Berdasarkan fakta-fakta yang telah dijelaskan di atas, akan dilaksanakan penelitian dengan judul "Pengaruh Pendidikan Agama Islam Terhadap Akhlak Peserta Didik” (Penelitian di MTs Al-Mansyur Kelas VIII Kecamatan Panjalu)

\section{Pendidikan Agama Islam}

Ahmad Tafsir (2005:45), mendefinisikan "Pendidikan Agama Islam sebagai bimbingan yang diberikan oleh seseorang agar ia berkembang secara maksimal sesuai dengn ajaran islam".

Abdul Madjid, 2005:130) mendefinisikan "Pendidikan Agama Islam sebagai suatu usaha untuk membina dan mengasuh peserta didik agar senantiasa dapat memahami ajaran Islam secara menyeluruh serta menghayati tujuan yang pada akhirnya dapat mengamalkan dan menjadikan Islam sebagai pandangan hidup".

Tujuan pokok pendidikan Islam ialah mendidik budi pekerti dan pendidikan jiwa. Tujuan yaitu sasaran yang akan dicapai oleh seseorang atau sekelompok orang yang melakukan suatu kegiatan. Karena itu pendidikan Islam, yaitu sasaran yang akan dicapai oleh seseorang atau sekelompok orang yang melaksanakan pendidikan Islam. Sesuai dengan firman Allah Swt dalam surat An Nahl ayat 64.

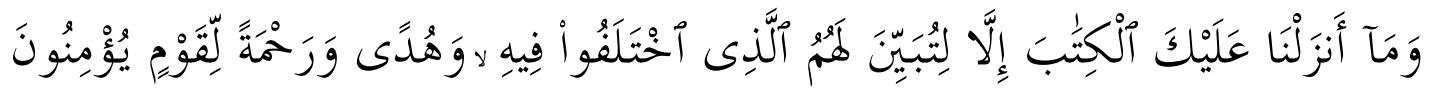


Artinya: dan kami tidak menurunkan kepadamu Al-Kitab (Al Quran) ini, melainkan agar kamu dapat menjelaskan kepada mereka apa yang mereka perselisihkan itu dan menjadi petunjuk dan rahmat bagi kaum yang beriman, (Tim Penerjemah Al Quran Kemenag RI, 2009:896).

Dapat disimpulkan bahwa tujuan pendidikan agama Islam adalah membimbing dan membentuk manusia menjadi hamba Allah yang saleh, teguh imannya, taat beribadah, dan berakhlak terpuji. Jadi, tujuan pendidikan agama Islam adalah berkisar kepada pembinaan pribadi muslim, yang terpadu pada perkembangan dari segi sepiritual, jasmani, emosi, intelektual, dan sosial. Atau lebih jelas lagi, ia berkisar pada pembinaan warga negara muslim yang baik, yang percaya pada Tuhan dan agamanya, berpegang teguh pada ajaran agamanya.

Oleh karena itu berbicara pendidikan agama Islam, baik makna maupun tujuannya haruslah mengacu pada penanaman nilai-nilai Islam dan tidak dibenarkan melupakan etika sosial atau moralitas sosial. Penanaman nilai-nilai ini juga dalam rangka menuai keberhasilan hidup di dunia maupun membuahkan kebaikan di akhirat kelak.

Pendidikan Islam sebagai ilmu, mempunyai ruang lingkup yang sangat luas, karena di dalamnya banyak pihak yang terlibat, baik secara langsung maupun tidak langsung.

Adapun ruang lingkup pendidikan Agama Islam menurut Nur Uhbiyati (2009:13) adalah sebagai berikut:

Yaitu landasan yang menjadi fundamen serta sumber dari segala kegiatan pendidikan Islam ini dilakukan. Yaitu membentuk anak didik menjadi manusia dewasa yang bertakwa kepada Allah dan berkepribadian muslim.

Materi Pendidikan Islam, yaitu bahan-bahan, pengalaman-pengalaman belajar ilmu agama Islam yang disusun sedemikian rupa untuk disajikan atau disampaikan kepada anak didik.

Metode Pendidikan Islam, yaitu cara yang paling tepat dilakukan oleh pendidikan untuk menyampaikan bahan atau materi pendidikan Islam kepada anak didik. Metode di sini mengemukakan bagaimana mengolah, menyusun dan menyajikan materi tersebut dapat dengan mudah diterima dan dimiliki oleh anak didik.

Evaluasi Pendidikan, yaitu memuat cara-cara bagaimana mengadakan evaluasi atau penilaian terhadap hasil belajar anak didik. Tujuan pendidikan Islam umumnya tidak dapat dicapai sekaligus, melainkan melalui proses tertentu. Apabila tahapini telah dicapai maka pelaksanaan pendidikan dapat dilanjutkan pada tahap berikutnya dan berakhir dengan terbentuknya kepribadian muslim.

\section{Akhlak Peserta Didik}

Akhlak secara etimologi adalah bentuk jamak dari khuluq yang berarti budi pekerti, perangai atau tabi'at. Menurut Imam Ghazali, sebagaimana dikutip Yunahar Ilyas (2010:2), "akhlak adalah sifat yang tertanam dalam jiwa yang menimbulkan perbuatan-perbuatan yang dengan mudah tanpa memerlukan pemikiran maupun pertimbangan". 
Menurut Mansur (2009:221), dalam pengertian sehari-hari akhlak umumnya disamakan artinya dengan budi pekerti, kesusilaan, sopan santun dalam bahasa Indonesia, dan tidak berbeda pula dengan arti kata moral, ethic dalam bahasa inggris. Manusia akan menjadi sempurna jika mempunyai akhlak terpuji serta menjauhkan segala akhlak tercela

Akhlak peserta didik dalam hal ini bukan hanya sekedar hal-hal yang berkaitan dengan ucapan, sikap dan perbuatan yang harus ditunjukkan oleh siswa baik dalam pergaulan di sekolah maupun di luar sekolah. Melainkan berbagai ketentuan lainnya yang memungkinkan dapat mendukung efektivitas proses belajar mengajar. Pengetahuan terhadap akhlak siswa ini bukan hanya perlu diketahui oleh setiap siswa dengan tujuan agar mengaplikasikannya dalam kehidupan sehari-hari, namun juga perlu diketahui oleh setiap guru, dengan tujuan agar dapat mengarahkan dan membimbing para siswa untuk mengikuti akhlak tersebut.

Ruang lingkup akhlak adalah sama dengan ruang lingkup ajaran Islam itu sendiri, khususnya yang berkaitan dengan pola hubungan akhlak dalam ajaran agama Islam mencakup berbagai aspek, dimulai dari akhlak terhadap Allah Swt, hingga kepada sesama makhluk ciptaan Allah SWT. (Muhammad Alim, 2006:152) adalah:

Akhlak Kepada Allah SWT, titik tolak akhlak kepada Allah adalah pengakuan dan kesadaran bahwa tiada Tuhan melainkan Allah. Sebagaimana firman Allah dalam AlQur'an surat An-Naml ayat 93, secara tegas dinyatakan-Nya bahwa:

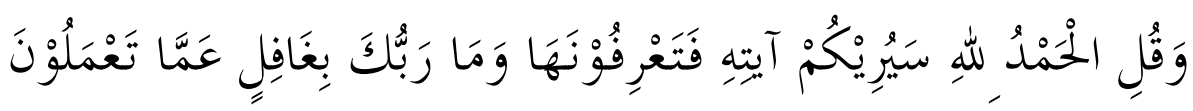

Artinya: Dan katakanlah, "Segala puji bagi Allah, dia akan memperlihatkan padamu tanda-tanda kebesaran-Nya, maka kamu akan mengetahuinya. Dan Tuhanmu tiada lalai dari apa yang kamu kerjakan. (Tim Penerjemaah Al Quran Kemenag RI, 2014:Qs. An-Naml ayat 93).

Akhlak Kepada Sesama Manusia, tidaklah wajar bila seseorang mengucilkan seseorang atau kelompok lain, tidak wajar pula berprasangka buruk tanpa alasan, atau menceritakan keburukan seseorang dan menyapa atau memanggilnya dengan sebutan yang buruk. Firman Allah dalam Al-Qur'an surat Al-Baqarah ayat 263 yang berbunyi:

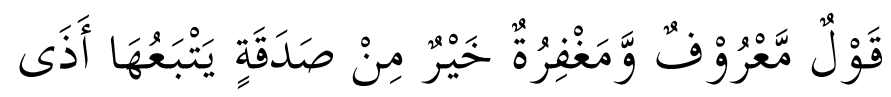

Artinya: Ucapan yang wajar lebih baik daripada sedekah yang disertai dengan sesuatu yang menyakitkan (perasaan si penerima). (Tim Penerjemaah Al Quran Kemenag RI, 2004:Qs.Al-Baqarah ayat 263).

Akhlak Kepada Lingkungan, yang dimaksud lingkungan di sini adalah segala sesuatu yang berada disekitar manusia, baik binatang, tumbuh-tumbuhan, maupun benda-benda tak bernyawa. Pada dasarnya akhlak diajarkan al-Qur'an terhadap lingkungan bersumber dari fungsi manusia sebagai khalifah. Kekhalifahan menuntut adanya interaksi antara manusia dengan sesamanya, dan manusia dengan alam. Kekhalifahan mengandung arti pengayoman, pemeliharaan, serta pembimbingan, agar setiap makhluk mencapai tujuan penciptaannya. 


\section{B. METODE}

Penelitian yang digunakan adalah metode deskriptif dengan pendekatan kuantitatif, yaitu data yang diperoleh dan dikumpulkan kemudian dianalisis berdasarkan metode yang diterapkan, dengan tujuan untuk mengetahui ada tidaknya pengaruh.

Populasi adalah nilai totalitas/keseluruhan subjek penelitian (Bejo Siswanto, 2012;15). Dalam penelitian ini, akan diambil sebagian populasi dari seluruh peserta didik MTs Al-Mansyur Hujungtiwu yang berjumlah 165 orang. Teknik sampling yang digunakan adalah teknik purposive sampling. Menurut Sugiyono (2010:218), "Purposive sampling adalah teknik pengambilan sampel sumber data dengan pertimbangan tertentu". Adapun alasannya dikarenakan tidak mungkin mempelajari semua yang menjadi anggota populasi karena keterbatasan, tenaga dan biaya serta waktu, maka akan diambil sampel dari kelas XII sebnyak 35 orang yang dianggap representative (mewakili) dan dianggap cocok dengan masalah penelitian. Berdasarkan teknik penarikan sampel yang digunakan, sampel dalam penelitian ini sebanyak 35 orang dengan ketentuan jumlah sampel berdasarkan jumlah anak kelas XII dengan alasan bahwa kelas sampel memiliki akhlak yang kurang baik di lingkungan sekolah.

Untuk menentukan data yang diperlukan maka dibutuhkan adanya teknik pengumpulan data agar fakta-fakta yang diperoleh berfungsi sebagai data objektif dan tidak terjadi penyimpangan dari keadaan yang sebenarnya untuk menggali data dari sumber yang telah ditentukan, maka diperlukan alat kerja untuk mengumpulkan data yang disebut dengan teknik atau metode pengumpulan data. Adapun metode yang diperlukan tersebut diantaranya adalah: Pedoman Observasi, Observasi langsung dalam meneliti/mengamati objek yang akan diteliti. Pedoman Wawancara, wawancara yang digunakan adalah jenis serta merta agar lebih dapat menyesuaikan dengan keadaan saat wawancara. Angket, angket yang digunakan adalah quisioner terbuka, sehingga responden mampu dengan bebas memberikan jawaban

Teknik Analisis Data digunakan untuk memberikan gambaran bagaimana kondisi tiap variabel penelitian. Pada penelitian ini teknik tahapan teknik analisis yang digunakan adalah analisis deskriptif, korelasi dan uji hipotesis. Analisis deskriptif digunakan untuk mengetahui kondisi tiap variabel. Analisis koefesien korelasi, digunakan untuk mengetahui pengaruh antar variabel. Mengingat data yang diperoleh berjenis data ordinal, maka untuk mempermudah proses analisis dan pengolahannya digunakan pendekatan rumus Rank dari Spearman, penggunaan rumus ini didasarkan bahwa korelasi rank paling mudah dan sederhana dibandingkan dengan rumus korelasi lainnya. Rumus rank spearmans tersebut yaitu.

$$
r s=\quad \text { (Wawan, dkk. 2015:110) }
$$

Menafsirkan harga koefesien korelasi, dengan kriteria sebagai berikut :

$0,00-0,19=$ Korelasi sangat rendah

$0,20-0,39=$ Korelasi rendah

$0,40-0,79=$ Korelasi cukup atau sedang

$0,80-1,00=$ Korelasi tinggi

(Wawan, dkk. 2015:110) 
Kriteria Pengujian:

Ha : terima, jika koefisien Rs mendekati 1

Ho : tolak, jika koefisien Rs mendekati -1

Pengujian koefisien determinasi

$\mathrm{KD}=\mathrm{Rs}^{2} \times 100 \%$

Criteria Pengujian:

$\mathrm{KD}=$ Mendekati 100, menyatakan koefisien determinasi sangat kuat.

$\mathrm{KD}=$ Mendekati 0, menyatakan koefisien determinasi sangat lemah.

Uji Hipotesis

Untuk pengujian hipotesis digunakan rumus sebagai berikut:

$t_{\text {tabel }}=\mathrm{t}(1-\alpha)(\mathrm{dk})$

Hipotesis penelitian yang diajukan adalah :

Sedangkan hipotesis statistik yang diajukan adalah:

$\mathrm{t}_{\text {hitung }} \geq \mathrm{t}_{\text {tabel }} \mathrm{H}_{\mathrm{a}}$ diterima dan $\mathrm{H}_{\mathrm{o}}$ ditolak

$\mathrm{t}_{\text {hitung }}<\mathrm{t}_{\text {tabel }} \mathrm{H}_{\mathrm{a}}$ diterima dan $\mathrm{H}_{\mathrm{o}}$ ditolak

Dengan keputusan pengujiannya sebagai berikut.

Ha :Semakin baik Pendidikan Agama Islam, maka semakin baik Akhlak peserta didik."

Ho : Semakin rendah Pendidikan Agama Islam, maka semakin rendah Akhlak peserta didik.

\section{HASIL DAN PEMBAHASAN}

\section{Pendidikan Agama Islam di MTs Al-Mansyur Hujungtiwu Kecamatan Panjalu}

Berdasarkan hasil penelitian dapat dijelaskan bahwa pelaksanaan Pendidikan Agama Islam di MTs Al-Mansyur Hujungtiwu Kecamatan Panjalu sudah dijalankan dengan baik artinya telah sesuai dengan kurikulum yang ditetapkan pemerintah pusat. Hal ini dengan dibuktikan perolehan nilai sebesar 67,3 dengan kriteria baik berada pada interval diatas 65,25 yang termasuk klasifikasi baik.

Hasil penelitian ini menjelaskan bahwa Pendidikan Agama Islam yang ada disekolah sangatlah penting artinya bagi pembinaan peserta didik. Karena Pendidikan Agama Islam adalah pengetahuan untuk membentuk akhlak agar segala perbuatannya sesuai dengan tuntutan yang ada dalam ajarannya. Kemudian pentingnya Pendidikan Agama Islam bagi seorang peserta didik, agar dalam kehidupan berbangsa dapat dilandaskan dengan pengetahuan yang didasari agama, jika seseorang telah diberikan Pendidikan Agama Islam, maka ia akan menjadi seseorang yang berbudi luhur yang penuh dengan akhlak mulia. Sesuai dengan tujuan Pendidikan Agama Islam bahwa Pendidikan Agama Islam merupakan suatu proses membimbing dan membina fitrah (kesucian) peserta didik secara maksimal dan bermuara pada terciptanya pribadi yang demikian, dalam hal ini peserta didik diharapkan akan mampu memadukan pengetahuan dengan akhlak yang mulia.

Pendidikan agama Islam pada hakekatnya tidak hanya dilaksanakan ketika akan dimulai jam pelajaran pendidikan agama Islam. akan tetapi dalam kehidupan sehari-hari 
yang telah menjadi kewajiban dari seorang muslim, baik berada di lingkungan sekolah maupun lingkungan keluarga dan masyarakat. Hal ini yang sebenarnya menjadi kewajiban peserta didik dalam menjalankan nilai-nilai pendidikan agama Islam dengan baik tanpa harus ada paksaan. Seperti kegiatan-kegiatan yang bersifat kehidupan seharihari, di luar jam pelajaran, perbuatan sesama manusia.

Pada akhirnya berhasil atau tidaknya Pendidikan Agama Islam tergantung kepada sampai sejauh mana para pendidik dalam menanamkan nilai-nilai ajaran Islam. Hubungan mereka akan dikatakan baik atau berhasil bila dibuktikan oleh pengetahuan dan sikap dalam bentuk pengalaman yang merupakan akhlak dirinya.

Hasil penelitian juga menunjukkan bahwa dalam pelaksanaan Pendidikan Agama Islam disekolah agar dapat berhasil dan tercapai, pada saat proses belajar mengajar cara guru dalam mengatasi peserta didik agar tidak jenuh dalam mengikuti pelajaran Pendidikan Agama Islam dan dapat dicerna atau diterima oleh peserta didik maka guru perlu menggunakan metode yang bervariasi yaitu menggunakan metode ceramah, tanya jawab, diskusi, dan kelompok. Karena kharisma seorang guru juga sangat menentukan sikap peserta didik dalam kegiatan belajar, guna mewujudkan tujuan yang akan dicapai. Selain itu agar peserta didik lebih semangat dalam mengikuti pelajaran Pendidikan Agama Islam maka guru memberikan cerita tentang kehidupan sehari-hari dan mengaitkannya materi yang sedang dibahas, serta memberikan motivasi-motivasi yang membangun dengan harapan agar peserta didik merubah sikap yang kurang baik dan memahami ajaran Islam di dalam kehidupannya.

\section{Akhlak Peserta Didik di MTs Al-Mansyur Hujungtiwu Kecamatan Panjalu}

Hasil penelitian telah menunjukkan bahwa, keadaan akhlak atau tingkah laku peserta didik di MTs Al-Mansyur Hujungtiwu Kecamatan Panjalu pada umumnya sudah cukup hal ini berdasarkan hasil penelitian diperoleh nilai sebesar 60,87 dengan kriteria termasuk baik karena berada diatas interval 59,11 klasifikasi baik. Walaupun ada beberapa peserta didik yang masih kurang baik. Guru mengharapkan sikap atau tingkah laku yang ditunjukkan peserta didik berperilaku yang baik, agar mencerminkan akhlak yang baik pula.

Selain itu guru juga mengharapkan peserta didik setelah mempelajari materi yang sudah disampaikan mampu memahami dan menerapkannya dalam kehidupan sehari-hari. Guru PAI maupun guru yang lainnya juga selalu berusaha mengajarkan sopan santun yang baik, mereka tidak hanya mengajarkan perkataan saja, tapi juga mengajarkannya dengan perbuatan, yaitu dengan memberikan tauladan dan contoh yang baik pada para peserta didik. Penanaman nilai moral dan spiritual seperti berdo'a bersama-sama sebelum memulai kegiatan pembelajaran juga sangat menentukan dalam membina tingkah laku peserta didik ke ranah yang lebih baik. Sehingga dalam mengikuti kegiatan proses belajar mengajar dikelas dapat berjalancar dan ilmu yang telah diterima dapat bermanfaat untuk kedepannya. Sampai berakhirnya proses pembelajaran dikelas peserta didik di wajibkan agar bersalaman dengan guru supaya terbiasa melakukan perilaku yang baik dan sopan santun 
Menurut Al-Ghazali (Langgulung, 2015:274), “Tingkah laku itu adalah mempunyai penggerak (motivasi), pendorong, tujuan dan objektif. Dan motivasi itu bersifat dari dalam yang muncul dari diri manusia sendiri”.

Hal tersebut sesuai dengan tingkah laku peserta didik yang ada di MTs AlMansyur Hujungtiwu Kecamatan Panjalu bahwa supaya pembinaan tingkah laku peserta didik dapat berhasil tercapai dengan baik maka pada saat di akhir pembelajaran, guru memberikan pesan-pesan yang baik dan motivasi-motivasi yang membangun kepada para peserta didik, bahwa mengamalkan pendidikan agama Islam bukan hanya dengan shalat lima waktu saja, tetapi juga saling menghormati/menghargai sesama teman, guru disekolah maupun jika bertemu dengan orang lain. Menghormati dan membantu orang tua dirumah dan saling tolong menolong terhadap sesama.Jadi, antara teori dengan penelitian yang peneliti lakukan telah sesuai, yakni agar dalam membina tingkah laku peserta didik dapat berhasil dan tercapi maka harus ada penggerak (motivasi), pendorong dan tujuan dari luar.

\section{Pengaruh Pendidikan Agama Islam terhadap akhlak peserta didik di MTs Al-Mansyur Hujungtiwu Kecamatan Panjalu}

Berdasarkan hasil penelitian dapat dijelaskan bahwa terdapat pengaruh Pendidikan Agama Islam terhadap Akhlak Peserta Didik di MTs Al-Mansyur Hujungtiwu Kecamatan Panjalu dengan nilai korelasi sebesar 0,80 dengan klasifikasi tinggi. Hal ini berarti pendidikan Agama Islam memiliki pengaruh yang tinggi terhadap akhlak peserta didik di MTs Al Mansur Kecamatan Panjalu Kabupaten Ciamis. Kontribusi yang diberikan Pendidikan Agama Islam dalam mempengaruhi akhlak peserta didik sebesar $64 \%$, dan sisanya sebesar $36 \%$ dipengaruhi faktor lain yang tidak disebutkan dalam penelitian ini seperti kebiasaan bergaul, teman bermain dan dukungan orang tua. Hasil pengujian signifikansi diperoleh nilai $t_{\text {hitung }}$ sebesar $=7.659$. Sedangkan $\mathrm{t}_{\text {tabel }}$ pada taraf signifikasi $0,05 \mathrm{dan} \mathrm{dk}(\mathrm{dk}=35-2=33)$ diperoleh $\mathrm{t}_{\text {tabel }}(0,95 / 32)=1,687$. Dengan demikian $t$ hitung 7.659 , sehingga Hipotesis Alternatif $\left(\mathrm{H}_{\mathrm{a}}\right)$ diterima sedangkan Hipotesis Nol $\left(\mathrm{H}_{\mathrm{o}}\right)$ ditolak. Jadi, terdapat pengaruh yang signifikan antara Pendidikan Agama Islam terhadap Akhlak peserta didik.

Hasil penelitian ini menunjukkan bahwa pendidikan Agama Islam merupakan salah satu faktor penting pada akhlak. Hal ini didukung oleh teorinya Yatimin Abdullah (2015:54) bahwa aspek yang mempengaruhi akhlak ada 7 yaitu tingkah laku manusia, insting/naluri, pola dasar bawahan, nafsu, adat/kebiasaan, lingkungan (alam dan pergaulan ;keluarga, sekolah, organisasi, teman, dll), kehendak/takdir.

\section{SIMPULAN}

Berdasarkan hasil penelitian yang telah diuraikan dalam bab empat, maka peneliti dapat mengambil kesimpulan sebagai berikut :

Pendidikan Agama Islam di MTs Al-Mansyur Hujungtiwu Kecamatan Panjalu sudah dijalankan dengan baik dibuktikan perolehan nilai sebesar 67,3 dengan kriteria baik berada pada interval diatas 65,25 yang termasuk klasifikasi baik. 
Akhlak Peserta Didik di MTs Al-Mansyur Hujungtiwu Kecamatan Panjalu pada umumnya sudah baik dibuktikan dengan nilai sebesar 60,87 dengan kriteria termasuk cukup karena berada diatas interval 59,11 klasifikasi baik.

Pengaruh Pendidikan Agama Islam terhadap akhlak peserta didik di MTs AlMansyur Hujungtiwu Kecamatan Panjalu tergolng tinggi dibuktikan dengan nilai korelasi sebesar 0,80 dengan klasifikasi tinggi. Derajat determinasi Pendidikan Agama Islam terhadap akhlak peserta didik sebesar 64\%, dan sisanya sebesar 36\% dipengaruhi faktor lain yang tidak diteliti pada penelitian ini. Terdapat pengaruh yang signifikan antara Pendidikan Agama Islam terhadap Akhlak peserta didik dibuktikan dengan nilai $\mathrm{t}$ hitung sebesar $=7.659$. Sedangkan $t$ tabel $=1,687$.

Berdasarkan temuan hasil penelitian di atas disarankan sebagai berikut : Agar lebih meningkatkan kemampuan dan pemahamannya dalam rangka mencapai tujuan pembelajaran dan pengajaranc.Agar lebih inovatif lagi dalam mengembangkan pembelajaran Pendidikan Agama Islam baik dalam kelas maupun di luar kelas. Menjadi manajer kelas yang mampu memimpin siswa menuju perubahan-perubahan baru untuk meningkatkan kualitas lulusan yang lebih baik

\section{DAFTAR PUSTAKA}

Arikunto Suharsimi, 2008. Prosedur penelitian (suatu pendekatan praktik). Jakarta :Rineka Cipta. .1996. Prosedur Penelitian Suatu Pendekatan Praktek. Jakarta: PT Rineke Cipta.

Abudin Nata. 2010. Metodologi Studi Islam. Jakarta: Raja Grafindo Persada.

Ahmad. D. Marimba. 1981. Pengantar Filsafat Pendidikan Islam. Bandung:al- Ma'rifat.

Ngalim Purwanto. 2005. Ilmu Pendidikan Teoritis dan Praktis. Bandung:Remaja Karya.

Barmawaie Umary. 2011. Akhlak yang mulia. Surabaya :Bina Ilmu.

HB. Siswanto. 2004. Prosedur dan Metode Penelitian. Fakultas Tarbiyah IAILM Suryalaya Tasikmalaya.

Hasbullah. 2005. Dasar-dasar Ilmu Pendidikan. Jakarta : Raja Grafindo Persada.

Muhamad Yunus. 1983. Filsafat Pendidikan Islam. Jakarta Ciputat Press.

Muhammad Athiyah Al-Abrasy. 1987. Moral dan Kognisi Islam. Bandung:Remaja Karya.

Moh. Ardani. 2005. Akhlak Tasawuf. Jakarta: Mitra Cahaya Utama.

Mahmud Ya'qub. 1996. Metodik Khusus Pendidikan Agama. Jakarta:Hidakarya.

Ramayulis. 2004. Ilmu Pendidikan Islam. Jakarta: Kalam Mulis.

Sugiyono.2008. Metode Penelitian Pendidikan Pendekatan Kuantitatif, Kualitatif, dan $R \& D$. Bandung: Alfabeta.

Zuhairini,dkk. Metodik Khusus Pendidikan Agama. Surabaya : Biro Ilmiah Fakultas Tarbiyah IAIN Sunan Ampel Malang.

Zakiah, Daradjat. 1992. Ilmu Jiwa Agama. Jakarta:Bumi Aksara.

Zahrudi AR. 2004. Pengantar Studi Ahlak. Jakarta : Raja Grafindo Persada.

Wawan, dkk. 2015. Pedoman Penyusunan Karya Tulis Ilmiah. Tasikmalaya. IAILM Suryalaya. 